\title{
ENGLISH-ESTONIAN CODE-COPYING IN ESTONIAN BLOGS
}

Helin Kask

Tallinn University

\begin{abstract}
The article discusses English-language impact on Estonian in online blogs. The data comprise blog entries from 15 Estonian fashion, beauty and lifestyle blogs from 2012 to February 2016. The corpus consists of 283 post entries (141,480 words (tokens)). The research showed that there are far fewer selective copies than global copies, probably because selective copies appear at more advanced stages of acquisition. Global copies are usually copied due to semantic specificity, for example fashion lexis (e.g. look, etc.). They are also copied due to their importance at the discourse level, for example god, oh well, etc.

Often the English something is done by someone and have-constructions are copied, as these are already habitualized in Estonian. There is also evidence of semantic copying, which causes changes in content or usage of unusual expressions under English influence.

There are also mixed copies, where global copies are used as lexical cores in copied combinational patterns (e.g. Eng. 'epic' used to form an adjective). A mixed copy often represents a transitory stage between a global copy and a selective copy; this might be the case in this research, as there were more mixed copies than selective ones. This might be because selective copies appear at more advanced stages of acquisition.
\end{abstract}

Keywords: code-copying, blogs, language contacts, English, Estonian

\section{Introduction}

After Estonia regained its independence in 1991 English-Estonian language contact intensified and several English loans have been established in Estonian (Leemets 2002: 41). English-language impact on Estonian and English-Estonian language contact have not been 
investigated, apart from studies on conventionalized lexical borrowings in Standard Estonian (Leemets 2003) and a handful of MA theses written within one or another contact linguistics theoretical framework and exploring the impact of English in internet communication (Igav 2013, Roosileht 2013, Vaba 2010).

Multilingual communication on the internet is of interest to a wide range of scholars, for instance, to researchers on language in virtual communities, innovative language use and language contacts (Androutsopoulos 2012, 2013b, 2015, Danet and Herring 2007, Herring 2012, Hinrichs 2006, Jaworska 2014, Dorleijn and Nortier 2009 and many others). The current article focuses on English impact on Estonian in beauty, fashion and lifestyle online blogs, where English has become a lingua franca and consequently there is greater exposure to English. The objective of the paper is to discuss why English is used and what types of copies are used the most. From the existing literature it is apparent that the main reasons for code-copying are semantic specificity and importance on a pragmatic level. I am going to show that the reason for copying depends on the type of copy in question.

Due to the rise of what is called 'superdiversity' (Vertovec 2007), there is a need to describe many new concepts; usually they are first described in English. Therefore, many English words and expressions are used in Estonian, some of which are copied, while others are adapted. The use of English is very common in the fields that develop and change rapidly, e.g., information technology. Contact with English is, therefore, both extensive (i.e., English appears in different types of text and oral communication, in which many are proficient) and intensive.

Over the years the importance of English has increased; it is considered as one of the principal lingua francas. Thirty-eight percent (38\%) of Estonians claim ability to speak English; the figure being higher among the younger generation (Kruusvall 2015: 77). According to Eurobarometer, $97 \%$ of Estonian students had learned English as part of their general studies, and in 2014 64\% of Estonians 
of secondary school age claimed their level in English was fluent or excellent (Ehala 2015: 195, based on MeeMa 2014). It is not, therefore, surprising that Estonian students consider English as the most important subject at school (Tammemägi, Ehala 2012: 249). It is also very common (for younger people) to be exposed to Englishlanguage entertainment and popular culture and use English in social networking online on a daily basis. The aim of this article is to describe how English affects the language use of 'bloggers' (blog authors) who live in Estonia but use English to read the English language blogs of other bloggers to keep abreast of developments and trends and how this affects their language use on their own Estonian-language (see also Soler-Carbonell 2014; Siiner and Vihalemm 2011).

The article is organized as follows. First, blogging and language use in blogs are discussed. After that data and informants are described. This is followed by an overview of the code-copying model that is used to analyse the data, which is analysed both quantitatively and qualitatively; distinctive or unique examples of all types of copies are presented and analysed. Lastly, a discussion is had and conclusions are presented.

\section{Blogging and language use in blogs}

A blog is a web journal that consists of posts in chronological order. A blog post can vary in length from that of a short note to an essay. Posts are usually written according to a schedule, for example every day or once a week. Blog posts are asynchronous monologs - the posts can be read days or even years after they are written. Usually, a blog is run by one person alone and its appearance reflects the personality of the blogger (Crystal 2007: 15, 240).

A blog can be about sports, a hobby, handicraft, a political view, etc., i.e. there are different reasons for writing a blog. For example, some blogs reflect radical views and it might be difficult to release articles about that topic in the mainstream media, so a blog is used 
to impart those ideas. Some blogs are run by a political party, a department of a university, a music store to inform their readers about the latest news, etc. However, mostly blogs are written by one person to express their ideas, everyday life and interests. According to Thurlow (et al 2004: 133), blogging might also have a communicative function - nowadays when people travel and move abroad blogging is a way to keep in touch with family or to communicate and socialise with fellow expats.

When analysing the language used in blogs it must be taken into account that bloggers might not always know who read their blogs. Due to this it differs from a normal conversation, where interlocutors have prior knowledge about each other and where it is possible to consider the command of language of the interlocutors or to agree on using a certain language.

According to Crystal (2007: 15-16), the language of blogs displays the process of writing in its naked, unedited form. The Internet is fluid, people are more creative, exploring different expressions and using fresh combinations of elements and a blogger can manifest her/ his own language policy. Because of this it is possible to explore multilingual language use and contact phenomena that do not appear in oral use, for example orthography and the use of new constituent order patterns or phrase structures. Blogs are therefore a good resource for the study of language use as they contain the material in naked form (see also Igav 2013, Roosileht 2013, Vaba 2010).

\section{Data and informants}

In this article 15 fashion, beauty and lifestyle blogs were analysed. Only public blogs were analysed. According to a recent study carried out by IPREX (see Kulper 2015) fashion is one of the main topics in Estonian blogs. The majority of Estonian fashion bloggers write in Estonian (albeit with copies from English), although some blogs have many or all entries in two languages (parallel texts that present more or less the same information). However, the text that appears 
second is not a precise translation of the first. All bloggers in the present study are female, likely due to the topic of the blogs. They are 19-30 years old and all reside in Estonia, mostly in Tallinn. They all have revealed at least their first name.

The blog posts analysed were written in 2012-2016. Every blog entry was saved as a separate file in the Notepad++ program, and language contact phenomena were annotated. These data form a corpus that consists of 283 files and 141,480 words (tokens) in total. There are 1,977 instances of code-copying (CC) - on the average there are 7 instances of CC in every blog post. The frequency of posting varies: some bloggers write every day, some once or twice a week. On average, there are 500 words per blog post, with a range of from just few sentences up to 1,000 words. In Table 1 below the number of blog posts each blogger wrote and the number of tokens and CC instances that occurred across all the posts are presented.

Table I: Number of CC instances

\begin{tabular}{|l|c|c|c|}
\hline Bloggers & Entries & Tokens & CC instances \\
\hline Blogger I & 32 & 12,835 & 138 \\
\hline Blogger 2 & 4 & 1,756 & 31 \\
\hline Blogger 3 & 20 & 12,116 & 178 \\
\hline Blogger 4 & 55 & 26,217 & 302 \\
\hline Blogger 5 & 33 & 24,268 & 229 \\
\hline Blogger 6 & 11 & 3,034 & 40 \\
\hline Blogger 7 & 1 & 486 & 2 \\
\hline Blogger 8 & 21 & 17,146 & 302 \\
\hline Blogger 9 & 4 & 2,218 & 26 \\
\hline Blogger I0 & 16 & 6,826 & 88 \\
\hline Blogger II & 49 & 13,744 & 274 \\
\hline Blogger I2 & 12 & 1,701 & 64 \\
\hline Blogger I3 & 4 & 601 & 14 \\
\hline Blogger I4 & 15 & 5,936 & 177 \\
\hline Blogger I5 & 6 & 12,596 & 1,977 \\
\hline TOTAL & 283 & 141,480 & \\
\hline
\end{tabular}


Most likely bloggers use English to read the English language blogs of other bloggers to keep abreast of fashion and beauty, but the use of English in blogs varies. Although $70-80 \%$ of Estonians in the age of 20-29 claim they speak English fluently or excellently (Ehala 2015: 195), it might be assumed that bloggers (subconsciously) limit the use of English because their aim is to write a monolingual text so the readers would understand it. However, considering the specific topic of the blogs it is likely that blog readers are also interested in fashion and beauty and are familiar with this kind of vocabulary.

\section{Code-copying in blogs}

The data were analysed qualitatively to find out the reasons for presence of English-Estonian CC. For this Johanson's code-copying model was used. In Estonia this model has been previously used by Verschik for Russian-Estonian CC $(2014,2011)$, Praakli for Finnish-Estonian CC (2009), Vaba for English-Estonian CC (2010), Paljasma for French-Estonian CC (2012), Igav for English-Estonian CC (2013), Pere for French-Estonian CC (2014), Joenurma for LatvianEstonian CC (2015) and by the present author for English-Estonian CC (2013).

The notion of code-copying is that linguistic elements (units and patterns) of language or code are copied to another. Copies of elements from a foreign model code are inserted into a basic code; usually the basic code is the speaker's first language (L1) and the model code is the second language (L2) (Johanson 2002: 289).

This model focuses on intraclausal CC. The clausal level is chosen, since it is easier to decide whether the basic code is A or B. In some cases it is difficult to define the basic code, since many linguistic elements of the model code are used - a clause may still be A-coded in spite of heavy amount of B-code elements. As a result, purely quantitative criteria are not sufficiently decisive when determining the basic code (Johanson 1993: 199). In this paper the basic code is Estonian and the model code is English. 
In this model the asymmetrical dominance relations of the codes are taken into account. Usually elements of a sociolinguistically dominating code $\mathrm{B}$ are copied into the dominated code $\mathrm{A}$. For example the dominating code may be associated with power or status among the speakers of the dominated code. However, the relation between dominating and dominated codes may vary considerably according to the contact situation. In this framework it is not relevant whether the codes are genetically related, the codes may be languages, geographical dialects, sociolects, etc. (Johanson 2002: 289-290).

In the context of the blogs analysed in this paper, the bloggers copy elements from the sociolinguistically dominating or 'strong' code English to the dominated or 'weak' code Estonian. This is the case of adoption; traditionally this is referred to as 'borrowing', etc. Vice versa, where speakers use their own variety in the dominating code B, this is called 'imposition'. Although bloggers may find that English and Estonian are equally dominant for them, English may be sociolinguistically dominant due to the fact that they receive information about the topic they blog about in English.

According to Johanson (2002: 292), all linguistic elements have four types of properties - material, semantical, combinational and frequential. All types of copies are closely related, differing only in terms of the scope of copying.

Material properties are sound features, accent patterns, phonotactic patterns, including pronunciation, accent, stress, intonation. Verschik (2008: 171) adds graphic properties, meaning that in written data orthography should also be taken into account. For example, sometimes the orthography of the basic code is retained, consider sniikpiik 'sneak peek' and khuul 'cool', where English words are written as if they were Estonian. In these cases only material properties are copied, but not graphic properties. The choice of orthography might be a compromise or indicative of creativity (Androutsopoulous 2009, Koutsogiannis and Mitsikopoulou 2003) or it could be an example of language play or a joke (Vaba 2010: 64). 
Semantic copying means that denotative or connotative content elements of the model code units serve as models and are copied onto units of the basic code. For example, with see on kõndimiskaugusel ('it is within walking distance') only the meaning and collocation of the English expression are copied. This is a word-for-word rendition (referred to as 'loan translation' by some researchers); the idiomatic Estonian equivalent is see on kiviviske kaugusel 'it's in a stone's throw?.

Combinational properties are word order, phrase structure, government, etc. Due to English influence a progressive construction (on tegemas 'is doing') is used in Estonian (Metslang 2006: 719). Often English word order 'something is done by someone' is used, for example olen toredate inimeste poolt ümbritsetud 'I'm surrounded by nice people'; idiomatic Estonian requires a different word order (mind ümbritsevad toredad inimesed 'nice people surround me'). The use of such constructions is not limited to blogs alone, but is to be found universally in Estonian.

Frequential properties means that the occurrence of a linguistic element might increase or decrease due to the influence of the model code. For example, everyday language use shows that the use of word omama 'have' has increased in Estonian and is in daily use.

According to the CC framework, all types of copies are closely related and differ only in terms of their scope. Copying of all properties would result in a global copy; if only certain properties are copied, the result would be a selective copy. In addition, there are mixed copies. A mixed copy is a multiple word item which is copied in a way such that some of its elements are global copies and some selective copies (Johanson 2002: 291-292).

\section{I. GLOBAL COPIES}

A global copy means that all the properties of the model code unit are copied, in other words, the unit of the model code is copied as a whole, including its form and functions. It can comprise one or 
more words, be morphemically simple or complex, and belong to open or closed word class.

Typical global copies tend to have a relatively specific meaning and due to their specific meaning these model code elements are attractive for copying. Model code elements are semantically specific because there is unlikely to exist a native element that matches its semantics completely or because the element marks something unique or is important to the informant; it can also mark contact with new culture or field (Backus, Verschik 2012: 19; Praakli 2009: 94; Backus 2001: 128). In this article it was found that the main reason for copying is filling in of lexical gaps. Basic vocabulary was not copied and remained in Estonian, e.g. king 'shoe', kleit 'dress', etc.

One reason for copying is importance on the pragmatic level. According to Matras (1998: 281), bilinguals prefer the discourse markers of the pragmatically dominant language. Matras suggests that their prominence at the discourse level is responsible for their copiability. Backus and Verschik (2012) also note that if an element is perceptually salient, for example because it occupies a special focus position in the clause, it becomes extra noticeable and this increases the element's copiability.

Due to semantic specificity mostly nouns and noun phrases were globally copied, but also some adjectives and verbs, and mostly English orthography was used. A number of bloggers used italics or quotation marks to mark the English words, thus demonstrating linguistic awareness.

(1) ta on kõige õigem inimene kollektsiooni 70ndate boho chic vibe'i edastama

'She is the right person to communicate the 70's boho chic vibe of the collection'

(2) theBalm Mary-Lou Manizer highlighter on üks parimaid turul 'theBalm Lou Manizer highlighter is one of the best on the market' 
As mentioned above, in some cases the global copy was written in Estonian orthography.

(3) Ja siin on ka sniikpiik ühest kleidist.

'And here is a sneak peek of one dress.'

There are mostly global copies that mark fashion lexis. Nowadays English has become the lingua franca in the fashion world; the descriptions of styles, materials, silhouettes, etc., for instance, are in English, even when the native tongue of the designers is not English.

(4) Sügise üks märksõnu on layering.

'One of the keywords for fall is layering.'

(5) soe kuid siiski sügisene look

'Warm, yet autumnal look'

(6) Kas sul on mõni eeskuju/ style icon, kelle stiili imetled?

'Do you have a role model / style icon, whose style you admire?'

Copies from English are also used a lot when writing about beauty products. Bloggers often follow YouTube beauty bloggers and order cosmetics and products from online shops, so they are used to naming these products in English.

(7) enne kui paned peale mis tahes meigi, tasub kasutada ka primerit 'Before you use any kind of makeup it is good to use a primer'

(8) Läike kohta pigment väga head, kuid ei ole päris liquid lipstick. 'The pigment is quite good for a lip gloss, but they're not liquid lipsticks.'

(9) esmalt ostsin stippling brush' i, siis põsepunapintsli 'First I bought a stippling brush, then a blush brush.'

Adjectives are globally copied to express informants emotions, feelings, attitudes. In the below examples the adjectives copied have a really strong expressive connotation. In example (12) the adjective might be attractive for copying because the song the blogger is referring to is in English. 
(10) Ma ei venita enam pikemalt, aga siiski enne kui lugema hakkate siis jagan teiega ka oma viimase ajal kõige lemmikumat laulu, mis on lihtsalt mesmerizing.

'I'm not going to stall any longer, but before you start reading I'm going to share my favourite song with you, it's just mesmerizing.'

In example (11) the informant used obsessed, which marks powerful emotion. One of the reasons for copying might also be that there isn't an exact equivalent or construction in Estonian. To express the same idea, a different construction would be used (see on mu kinnisidee 'this is my obsession').

(11) jah ma olen jätkuvalt obsessed mustvalgetest fotodest :D

'Yes, I'm still obsessed with black and white photos :D'

The names of different shades of colours are also copied. In Estonian there are few prefixes to mark different shades of colours: mostly hele 'light', tume 'dark', erk 'bright' are used. In English the colour palette is much wider.

(12) Sametist saapad (burgungy värvi)

'Velvet boots (in burgundy)'

(13) enne nendesse süvenemist näitan ära selle talve põhivärvid: oxblood red ja military green

'Before moving on I introduce the main colours of this winter: oxblood red and military green.'

Verbs that are associated with certain websites are copied often. These are usually verbs that are used in blogging environments and on Facebook.

In example (14) the English verb share is copied. Lots of web sites offer the possibility of sharing the content of that web site with your friends through social networks, for example Facebook. So even though there is a short and semantical equivalent in Estonian informants prefer the English word. The reason for this might be that the word share is associated with a certain subculture and informants 
are already familiar with this word; it is also a part of the semantic frame of online culture.

(14) ja muidugi sundis see video otsima mind ülesse meie täispika video..ja sheerin jälle:)

'And of course this video made me look up our full-length video .. and I share it again :)'

The same is with the verb follow.

(15) Võite mind julgelt seal [Instagramis] follow'ida.

'You can easily follow me there [in Instagram].'

In example (16) the word like is copied. This verb has strong associations with Facebook, so again it refers to a specific subculture. In Estonian the word-for-word rendition (sulle peab meeldima 'you have to like') is not used, so to express the same idea, a different expression and construction would be used („vajuta nuppu meeldib“ 'press the like-button'). So here English like is used due to the lack of an Estonian equivalent construction and to achieve linguistic economy (Praakli 2009).

(16) Pead like'ima LET HER SPEAKi facebooki lehte.

'You have to like the LET HER SPEAK Facebook page.'

Several phrasal verbs were globally copied. These are semantically specific because there isn't an equivalent in Estonian that matches its semantics completely. Also the reason for using these phrasal verbs might be to achieve some kind of linguistic economy, because the English verb is short and fitting. This has also been noticed in Estonian-Russian (Verschik 2008: 135; 2007) and Estonian-Finnish contact situations (Praakli 2009: 149-156).

(17) Nii, et cozy night saunaga coming up :)

'So cozy night with sauna coming up :)'

(18) Kui kellelgi on mingeid soove, millist postitust ta tahab näha siis speak up ja teen ära selle:)

'If anybody has a wish, what kind of posts s/he wants to see, then speak up and I'll do it :)' 
(19) Igastahes help me out sel teemal.

'Anyway, help me out in this.'

As stated above, discourse markers from the pragmatically dominant language are preferred. Global copies included particles, interjections, adverbs and interrogative words, but no conjunctions were copied. Igav (2013: 38-54) also reached the same results.

In examples (20) and (21) the English adverb is globally copied; the reason might be that the informant thinks that the English word emphasizes the meaning more than the Estonian word.

(20) Mitte küll täpselt samad, obviously, leidsin ma need prillid ebay'st!

'Not exactly the same, obviously, I found these glasses on ebay!'

(21) saan kohtuda reaalselt kõige-kõige huvitavamate persoonidega keda ma üldse suudan ette kujutada ja ofc külastada Eo „inkubaatoreid“

'I get to meet people who are the most interesting I can imagine and ofc [of course] I can visit Eo incubators.'

The English interjection god was globally copied several times.

(22) God, ma mäletan neid näägutamisi „pane kurk kinni, müts pähe, sukapüksid jalga" haha.

'God, I remember nagging „wear a scarf, wear a hat, put on your tights" haha.'

(23) God, ma elan kaugel.

'God, I live far.'

In examples (24) and (25) oh well is used. The meaning of the word well depends on the context. According to Aijmer and Simon-Vandenbergen (2006: 1123) well can be used to express very different emotions, such as surprise or reluctance, also politeness and hesitation. The reason for copying might also be that there isn't an exact equivalent in Estonian and also for the pragmatic impact. 
(24) Oh well, ütlen otse, väga halb on.

'Oh well, I'll say it straight out, it's very bad.'

(25) unustasin isegi teile häid jõule soovida. Oh well...

'I even forgot to wish you marry Christmas. Oh well...'

Although according to Matras (1998: 293, 311), conjunctions are also usually copied, in my data there were no such examples; Igav (2013) similarly found no examples in her data. Paljasma (2012: 49) suggests that this might depend on the intensity of language contacts. However, the use of foreign conjunctions in Estonian has been noted: in Spanish-Estonian language contact in Argentina (Jürgenson 2010: 254) and in Portuguese-Estonian language contact in Brazil (Jürisson 2010: 298).

\subsection{SELECTIVE COPIES}

Selective copying means that only one or some, but not all properties are copied. The similarity of basic and model code elements can favour copying. According to Johanson (1993: 211) selective copying is used more when speakers are more proficient in the model code. The differences between basic and model code elements are not that salient; for example, if there are no English words present, it may seem at first glance that the construction is (wholly) from the basic code, so it might not be easy to decide that the element is from the model code.

As bloggers use English to a great extent on an everyday basis, it can be assumed that the main reason for selective copying is frequency. Bilinguals who use model code often have a good command of that language's grammatical patterns, especially the ones that are needed frequently and so they become productive. Frequency makes foreign patterns, word order, etc. attractive for copying.

I mentioned above that the have-construction and the word order something is done by someone are used in Estonian often due to English influences. These constructions are already conventionalized in Estonian. 
(26) oman üht 200 eurost acne salli

'I have an acne scarf that cost 200 euros.'

(27) ma olen täitsa olemas, elus, Tallinnas, hea tervise korras nüüd ja superõnnelik+ toredate inimeste poolt ümbritsetud

'I'm here, I'm alive, in Tallinn, in good health now and super happy + I'm surrounded by nice people.'

There are few examples of copying semantic and combinational properties.

In English the word walk has several meaning; Estonian has different words to mark types of walks. In example (28) the informant translates the meaning word-for-word whereas in Estonian a different phrasing would be used - see on kiviviske kaugusel 'it's in a stone's throw'.

(28) veel palju parem on kohale minna, asub PTI Group firma kontorist kõndimiskaugusel.

'It's much better to go there personally, it is within walking distance from PTI Group's office.'

In example (29) the English phrase structure is used. In Estonian this construction should be in the genitive: denim-Sg-GEN + white lace-Sg-GEN or simple white shirt-Sg-GEN combination-Sg-NOM, but in English these attributes are in the nominative.

(29) Ärme alustagi teksa + valge pits või lihtne valge särk kombinatsioonist, see töötab mu meelest alati ja imeliselt 'Don't even get me started with the combination of denim + white lace or simple white shirt, I think it always works amazingly.'

\subsection{MIXED COPIES}

Mixed copies are copies where one part is copied globally due to semantic specificity and other parts are copied selectively, mainly combinational. Mostly these are compound nouns and fixed word 
combinations. Johanson (1993: 215) suggests that mixed copies might be a transitory stage between global and selective copies.

In my data mixed copies were mostly compound nouns, although there were some adjectives, too.

(30) neid näete juba üsna pea outfiti postitustes

'You will see them soon in an outfit posts.'

(31) ja need on mul neljandad (viiendad?) clip-in salgud 'And these are my fourth (fifth?) clip-in hair extensions.'

(32) Õrnas nude-roosas toonis mahukas käekott unikaalse disaini ja ilusate detailidega.

'A capacious handbag in nude-pink with unique design and beautiful details'

(33) Esiteks, mis oleks selline pool casual, aga võib kontsa ka alla lükata, kui äri vaja teha.

'First, this would be half-casual, but for business meeting you can wear heels.'

There is an interesting mixed copy in the next example. A traditional meaning of the word epic is heroic. Nowadays it can also be used, especially in the language of young people, as a prefix, meaning 'huge and powerful'. In this example it is also used to emphasise the meaning.

(34) See nädal oli epic-kiire ja seda päris mitmel põhjusel.

'This week was epic-busy and that was for several reasons.'

To find out what types of copies prevail in my data, the corpus was analysed quantitatively with the program Corpus Stat. The analyse showed that global copies prevail - there were 1,772 global copies (90.5\%), 148 mixed copies (7.5\%) and only 39 selective copies (2\%). On the average there were 500 words and 7 instances of CC in a blog post. 


\section{Discussion and conclusions}

In this article English-Estonian code-copying in Estonians blogs was analysed. Blog posts were used because the language of blogs displays the process of writing in its naked, unedited form. Fifteen (15) fashion, beauty and lifestyle blogs run by Estonians were studied. The blog posts were written in 2012-2016.

For qualitative analysis of the data Johanson's code-copying model was used. This model helps us to flexibly describe and analyse context-dependant language change. This model subdivides copies into global, selective and mixed copying, depending on whether all or only certain properties of an element are copied.

This paper focused on how many and what type of copies were employed and what the reasons for code-copying (potentially) were. A quantitative analysis showed that global copies prevailed - $90.5 \%$ of the copies are copied globally, 7.5\% were mixed copies and $2 \%$ were selective copies. The reason why there were so few selective copies might be that selective copies are a transitory stage between global and mixed copies. When informants are more proficient in the model code, they utilise more selective copies.

The main reason for global copying is semantic specificity or pragmatic meaning. Mostly nouns and noun phrases were copied globally, the reasons being a lack of an equivalent in Estonian, the model code element marking something unique or important to the informant or contact with new culture or field. As English is the lingua franca in fashion, the topic might also favour global copies.

Adjectives were copied to express strong emotions and feelings; a separate category was copying colour terminology. Verbs that were copied are mostly associated with certain websites, for example Facebook, and blogging sites.

Due to the importance at the pragmatic level discourse particles were copied; this includes particles, adverbs, interjections and interrogatives. Discourse particles were used to intensify the meaning, to 
express surprise and emotions. There were no examples of copying of conjunctions (Igav 2013 had similar findings).

The main reason for selective copying is frequency - when informants use the model language often they consequently develop a good command of that language's grammatical patterns and so they start using those patterns in the basic code; selective copies appear, therefore, when the informant has used the model code for some time. In my data, there were few selective copies. Mostly have-construction and something is done by someone were copied; however, these constructions are conventionalized in Estonian and are often also used on a daily basis in other domains.

In my data there were more mixed copies than selective copies. As the mixed copies were compound nouns, where one part was copied globally, it suggests that mixed copies are a transitory stage. In mixed copies the global copying appeared due to semantic specificity and selectively combinational properties were copied.

For further conclusions, oral speech should be investigated. Based on everyday experience, English-Estonian bilingual speech is rather common; however, no research on English impact in oral speech has yet been undertaken. Although blogs are highly personalized, oral speech is more immediate and spontaneous and might also reveal interesting linguistic behaviour. Furthermore, data about the informants' proficiency in English and interviews with the informants might provide some thoughtful insight on the reasons for copying.

\section{REFERENCES}

Aijmer, Karin; Anne-Marie Simon-Vandenbergen 2006. The discourse particle well and its equivalents in Swedish and Dutch. - Linguistics 41-6, pp. 1123-1161.

Androutsopoulos, Jannis. 2006. Mehrsprachigkeit im deutschen Internet: Sprachwahl und Sprachwechsel. - Ethno-Portalen. P. Schlobinski, (Hg.), Von ${ }^{*}$ hdl $^{\star}$ bis ${ }^{*}$ cul8r${ }^{\star}$. Sprache und Kommunikation in den Neuen Medien, Mannheim: Dudenverlag (= Thema Deutsch, Band 7), pp. 172196. 
Backus, Ad 2001. The role of semantic specificity in insertional codeswitching: evidence from Dutch-Turkish. - Codeswitching Worldwide II. Ed. R. Jacobson. Berlin, New York: Mouton de Gruyter, pp. 125-154.

Backus, Ad; Anna Verschik 2012. Copiability of (bound) morphology. Copies versus Cognates in Bound Morphology. Volume 2. Eds. L. Johanson, M. Robbeets. Boston, Leiden: BRILL, pp. 1-32.

Blommaert, Jan 2010. The Sociolinguistics of Globalization. Cambridge: Cambridge University Press.

Crystal, David 2007. Language and the Internet. Cambridge, New York: Cambridge University Press.

Ehala, Martin 2015. Sustainability of Estonian language. - Estonian Human Development Report 2014/2015. (Ed.) R. Vetik. Tallinn: SA Eesti Koostöökoda, pp. 191-198.

Eurostat 2016. Foreign language learning statistics. http://ec.europa.eu/ eurostat/statistics-explained/index.php/Foreign_language_learning_ statistics. (11.04.2016)

Fanshawe, Simon; Dhananjayan Sriskandarajah 2010. You can't put me in a box. - Super-diversity and the End of Identity Politics in Britain. Institute for Public Policy Research.

Fraser, Bruce 1996. Pragmatic markers. - Pragmatics, nr 6(2), pp. 167-190.

Igav, Reet 2013. Inglise-eesti koodikopeerimine Facebooki vestlustes [English-Estonian Code-Copying in Facebook Conversations]. Master's Thesis. Tallinn University.

Joenurma, Elina 2016. Eesti-Läti kakskeelse isiku keelekasutus [EstonianLativian Bilingual Speech]. Master's Thesis. Tallinn University.

Johanson, Lars 1993. Code-opying in immigrant Turkish. - Immigrant Languages in Europe. (Eds.) G. Extra, L. Verhoeven. Clevedon, Philadelphia, Adelaide, pp. 197-221.

Johanson, Lars 2002. Contact-induced linguistic change in a code-copying framework. - Language Change: The Interplay of Internal, External and Extra-linguistic Factors. Eds. M. C. Jones, E. Esch. (Contributions to the Sociology of Language, 86.) Berlin: Mouton de Gruyter, pp. 285-313. Jürgenson, Aivar 2010. Eestlased ja eesti keel Argentiinas. - Eestlased ja eesti keel välismaal. [Estonians and the Estonian language in Argentina. Estonians and the Estonian Language Abroad.] Eds. Kristiina Praakli ja Jüri Viikberg. Tallinn: Eesti Keele Sihtasutus, pp. 239-264. 
Jürgenson, Aivar; Jürisson, Sander 2010. Eestlased ja eesti keel Brasiilias. Eestlased ja eesti keel välismaal. [Estonians and the Estonian language in Brazil. - Estonians and the Estonian Language Abroad.] Eds. Kristiina Praakli ja Jüri Viikberg. Tallinn: Eesti Keele Sihtasutus, pp. 285-304.

Koutsogiannis, Dimitris; Mitsikopoulou, Bessie 2003. Greeklish and Greekness: Trends and discourses of „Glocalness“. - Computer Mediated Communication 9 (1), http://jcmc.indiana.edu/vol9/issuel/kouts_mits.html.

Kruusvall, Jüri 2015. Keelteoskus ja keelte praktiline kasutamine. - Eesti ühiskonna lõimumismonitooring 2015. [Language skills and the practical use of languages. - Monitoring of Integration in Estonian Society in 2015.] In: Kristina Kallas, Raivo Vetik, Jüri Kruusvall, Ellu Saar, Jelena Helemäe, Laura Kirss, Cenely Leppik, Külliki Seppel, Kats Kivistik, Pille Ubakivi-Hadachi. Tartu: Haridus- ja Teadusministeerium.

Kulper, Kersti 2015. Eesti keskmine blogija: 29-aastane naine, kes kirjutab toidust, moest ja ilust. [The average blogger in Estonia: a 29 year-oldwoman who writes about food, fashion and beauty.] - Postimees, http:// naine24.postimees.ee/3152991/eesti-keskmine-blogija-29-aastanenaine-kes-kirjutab-toidust-moest-ja-ilust.

Leemets, Tiina 2002. Mullivann, peenema nimega jaccusi. [How to name a jaccuzi in Estonian.] - Oma Keel, 1, pp. 41-46.

Leemets, Tiina 2003. Inglise laenud sajandivahetuse eesti keeles. [English borrowings in Estonian at the turn of the century.] - Keel ja Kirjandus, 8, pp. 571-584.

Matras, Yaron 1998. Utterance modifiers and universals of grammatical borrowing. - Linguistics 36-2. Berlin: Mouton de Gruyter, pp. 281-331.

Matras, Yaron 2009. Language Contact. Cambridge, New York: Cambridge University Press.

MeeMa 2014. Keeleoskus ja võõrkeelte kasutamine Eestis eestlaste ja mitteeestlaste seas. - Mina. Maailm. Meedia. TÜ Ühiskonnateaduste Instituudi sotsioloogiline uuring. [Language skills and the use of foreign languages in Estonia among Estonians and non-Estonians. - Me. The World. The Media. A Sociological Study by the Institute of Social Studies of the University of Tartu.] Tartu: Saar Poll.

Mestlang, Helle 2006. Predikaat ajastut kogemas. [Predicate - the experiencer of the era.] - Keel ja Kirjandus, 9, pp. 714-727. 
Paljasma, Veronika 2012. Prantsuse-eesti koodikopeerimine blogides [FrenchEstonian Code-Copying in Blogs]. Master's Thesis. Tallinn University.

Pere, Kärt-Katrin 2014. Koodikopeerimine Pariisi eestlaste suulistes vestlustes [Code-Copying in Oral Conversations of Parisian Estonians]. Master's Thesis. Tallinn University.

Praakli, Kristiina 2009. Esimese põlvkonna Soome eestlaste kakskeelne keelekasutus ja koodikopeerimine. [Bilingual Language Use by First Generation Estonians in Finland and Code-Copying.] Doctoral Thesis. Tartu: Tartu Ülikooli Kirjastus.

Roosileht, Helin 2013. Inglise-eesti koodikopeerimine blogides [EnglishEstonian Code-Copying in Blogs]. Master's Thesis. Tallinn University.

Soler-Carbonell, Josep 2014. University language policy and language choice among $\mathrm{PhD}$ graduates in Estonia: The (unbalanced) interplay between English and Estonian. - Multilingua, 33(3-4), pp. 413-436.

Tammemägi, Anni; Ehala, Martin 2012. Eesti õpilaste keelehoiakud 2011. aastal. [Language attitudes of Estonian School students in 2011] - Keel ja Kirjandus, 4, pp. 241-260.

Thurlow, Crispin; Lengel, Laura B.; Tomic, Alice 2004. Computer Mediated Communication: Social Interaction and the Internet. London: SAGE.

Vaba, Marja 2010. Inglise-eesti koodikopeerimisest Tallinna Skype’i kontori kahe vestlusgrupi näitel [English-Estonian Code-Copying on the Example of Two Chat Groups at Skype Tallinn Office]. Master's Thesis. Tallinn University.

Vihalemm, Triin; Siiner, Maarja 2011. Balti riikide lõimumis- ja keelepoliitika Euroopa Liidu kontekstis. - Eesti inimarengu aruanne 2010/2011. [Language and integration policies of the Baltic states in the EU. - Estonian Human Development Report 2010/2011.] Eesti Koostöö Kogu, pp. 118-121.

Verschik, Anna 2007. Keelekontaktid, laenatavus ja verbi kopeerimine eestivene keelevariandis. [Copying of verbs in Estonia's Russian.] - Keel ja Kirjandus, 5, pp. 357-377.

Verschik, Anna 2008. Emerging Bilingual Speech: from Monolingualism to Code-copying. London, New York: Continuum.

Verschik, Anna 2011. Russian-Estonian code-copying in Live Journal blogs: A preliminary overview. - Slavica Helsingiensia, pp. 355-365. 
Verschik, Anna 2014. Estonian-Russian code-copying in Russian-language blogs: Language change and a new kind of linguistic awareness. - Negotiating Linguistic Identity. (Ed.) Vihman, Virve Anneli \& Praakli, Kristiina. Oxford, Bern, Berlin, Brussels, Frankfurt am Main, New York: Peter Lang Europäischer Verlag der Wissenschaften. (Nationalism Across the Globe; 14), pp. 59-87.

Vertovec, Steven 2007. Super-diversity and its implications. - Ethnic and Racial Studies 29(6), pp. 1024-1054.

Wertheim, Suzanne 2003. Discourse pragmatics as a means of contactinduced change. - Selected Proceedings of the CLIC-LISO Ninth Annual Conference on Language, Interaction and Culture, pp. 1-18. http:// www.suzannewertheim.com/publications/CLIC-LISO.pdf (06.02.2013) 